\title{
Immuno-histochemical study of the expression of ICAM-1 in the skin of mice under the effect of exposure to ultra violet rays type-B, before and after topical Retinoic acid
}

\author{
Somaya H. Mohamed*, Fouad M. Badr*, Howayda Abed El-Aal ${ }^{\dagger}$, Rushdy W. \\ Mohamed $^{\ddagger}$, and Bassem S. Ahmed ${ }^{\bullet}$
}

From Departments of Histology*, Pathology $y^{\dagger}$ and Dermatology ${ }^{\ddagger}$ Suez Canal Faculty of Medicine and Histology department Al-Azhar Faculty of Medicine - Assuit ${ }^{\bullet}$

\begin{abstract}
The exposure to ultraviolet radiations (UVR) become a medical problem, not just cosmetics or aesthetic concern, but for their skin photoaging and photodamage.

The naturally and synthetic derivatives of vitamin A (Retinoids) may have a role in treatment and prophylaxis against skin photodamage.

The current work studied the effect of ultraviolet-B rays on the ICAM-1 expression of mice's skin, before and after topical retinoids acid.

Thirty-six mice were subjected to ultraviolet-B rays in dose of $1.4 \mathrm{~J} / \mathrm{cm}^{2}$ for 15 minutes every other day for 10 weeks. The mice were subdivided into 3 equal groups; Radiated, Prophylactic, Treated, besides the non-exposed skin samples, which considered as control group. The prophylactic mice were subjected to topical Retinoic acid one day before UVR exposure, the mice of treated groups were subjected to topical Retinoic acid after the last UVR exposure 3 times weekly for 10 weeks.

Paraffin sections slides were prepared and stained with Hematoxylin and eosin stains for study the morphology.

The immuno-histochemical study for detection of ICAM-1 expression was performed using labeled streptavidin biotin technique (Dako) with the monoclonal antibody IICAM-1 (G5)\}.

The ICAM-1 expression was evaluated as optical density, and the obtained data was statistically analyzed by using student's t-test.

The study revealed a clinical signs of photodamaged skin only in radiated group mice. Histologically epidermal thickness associated with keratinocytic atypia, and necrotic cells were observed in radiated group mice. There was a statistically significant increase in the optical density of ICAM-1 expression in radiated and prophylactic groups mice $(p<0.001$ and $p<0.005$ respectively)..

The study concluded that retinoic acid given after UVB completely reversed the morphological, histological and ICAM-1 expression changes induced by UVB exposure and retinoic acid given before UVB prevented some of the morphological, histological and ICAM-1 expression changes induced by UVB exposure.
\end{abstract}

\section{Introduction}

Repeated exposure to UVR leads to chronic changes in the appearance and function of the skin described as Photoaging and photodamage (Kaminar, 1995). The most prevalent and well-known source of UVR is the sun. Phototherapy is an additional potential source and tanning beds have become a popular source of artificial UVR (Fitzpatrick, 1997).

Photoaging and photodamage include; wrinkles (fine and coarse), roughness, laxity, mottled pigmentation, actinic (lentigines and keratosis), scaling, xerosis and telangiectasia (Leyden, 2001). 
A prophylactic measures to minimize human cutaneous UVR exposures include, adsorbent, reflectant or combination sunscreen (Diffey, 1996). Treatment of photoaged skin is done by topical therapies to reverse photoaging includes the use of retinoids, alphahydroxy acid and antioxidants in addition to sunscreen.

The term retinoid includes both the naturally and synthetic derivatives of vitamin A. Retinoids have a role in regulating morphogenesis, vision, cellular proliferation, differentiation and matrix production. Many studies revealed that retinoids can be benefit in the treatment of photodamaged skin (Chen et al., 1992; DiGiovanna and Bethesda 1992; Oliver et al., 1995). Topical retinoids are also used in the treatment of acne, psoriasis, and promoting wound healing and systemic retinoids protect against cancer (Chu Hsu 1998).

Cell adhesion molecules (CAM) involved in the cell to cell adhesion required for inflammation. The members of this super-family (LFA-3 (CD58), ICAM(1-3), VCAM-1 and PECAM-1) are characterized by the presence of one or more immunoglobulin homology regions, each consisting of disulfide - bridged loop (Gearing and Newman 1994). The chief function of CAM is to bind leucocytes to cell expressing them, or to endothelium to facilitate vascular emigration or to cytosine activating fibroblasts and keratinocytes to aggregate leucocytes at sites of inflammation (Lobb, 1992). ICAM-1 is expressed lightly on normal endothelium. However, normal keratinocytes don't express ICAM-1 when examined by usual immunohistochemical methods, although extremely small amounts are detectable by electron microscopy. This expression may be sufficient for normal leucocytes and Langerhans cell migration (Lonati et al., 1996).

The role of topical retinoids in the treatment of photoaging was assessed in many studies. However, no available studies were done to investigate its preventive and therapeutic role of retinoic acid on UVB induced skin using immuno-histochemical ICAM-1 expression technique.

\section{Materials and Methods}

Thirty-six adult male mice were subjected to the study. A pre-defined shaved area of $2 \mathrm{~cm} \times 2 \mathrm{~cm}$ was selected in the back of each for ultraviolet exposure. Ultraviolet B rays was obtained by using Fs-40 sun-lamp produced $1.4 \mathrm{~J} / \mathrm{cm}^{2}$ of wavelength $290-320 \mathrm{~nm}$. The lamp was placed $25 \mathrm{~cm}$ from the back of mice for 15 minutes per session, on alternate days for 10 weeks (Chen et al 1992).

The mice were subdivided into 3 equal groups; Radiated, Prophylactic and Treated. All mice were exposed to UVB, Radiated group mice didn't subject to local retinoic acid application.

The prophylactic group mice were subjected to local retinoic acid application one day before exposure to UVB, while treated group mice were subjected UVB exposure followed by local retinoic acid administration 3 times per week for 10 weeks after last exposure.

The topical Retinoic acid was product of Ciba-Gigy (Retin A $0.05 \%$ ointment). The dose was $1 / 5$ finger tip point (finger tip unit $=$ amount of cream or ointment sufficient to cover $20 \mathrm{~cm} 2$ of skin) was applied to the mice shaved area. (Chaqour, et al., 1997)

Mice were sacrificed after $24 \mathrm{hrs}$ of last exposure to ultraviolet rays. Two skin biopsies were taken from all mice; one from the exposed area and represent experimental (Radiated, Prophylactic and Treated) samples and the other from non-exposed area and represented a control sample for each mice.

The skin biopsies were fixed in neutral buffered formol and processed for preparation of $4 \mathrm{um}$ thick paraffin section slides.

The paraffin sections were stained by Hematoxylin and Eosin stain for morphological change.

Immuno-histochemical technique for detection of ICAM-1 expression was performed using labeled streptavidin biotin technique (Dako) with the monoclonal antibody \{ICAM-1 (G-5)\}. 
The localization of ICAM-1 was demonstrated as yellowish brown color area. (Shi et al., 1991, Taylor et al., 1994).

Evaluation of ICAM-1 expression was done by the aid of Leica Image analyzer system as an optical density on 20 slide fields per biopsy (240 readings per group).

The obtained data were statistically analyzed using student t-Test for comparison between exposed and non-exposed areas for all groups.

\section{Results}

\section{Clinical Findings:}

\section{Exposed Skin:}

\section{Radiated Group}

The shaved area of the mice's skin appeared erythematous in the first 3 weeks. After $6^{\text {th }}$ week, the exposed skin showed marked mottled, pigmentation, longitudinal creases (wrinkles), laxity and scales (signs of photodamage).

\section{Prophylactic Group}

The exposed area of mice of this group showed mild mottled pigmentation, and no creases, laxity or scales.

\section{Treated Group}

The shaved area of the mice's skin appeared erythematous in the first 3 weeks. After $6^{\text {th }}$ week, signs of skin photodamaged were observed. After retinoic acid application, moderate clinical improvement of the photodamaged skin was noticed at the $14^{\text {th }}$ week. At the end of 10 weeks administration the skin appeared nearly similar to non-exposed skin.

\section{Morphometric Results: (Plate -1 )} Non-exposed Skin: (Control Group)

The normal non-exposed skin of mice showed very thin epidermis, with illdefined strata, stratum basale cells had clear oval nuclei (Plate1-A and Plate1-B).

Exposed Skin:

Radiated Group

In the area exposed to ultraviolet B, skin showed an increase in the epidermal thickness (Plate1-C) associated with necrotic cells in the form of vacuolated cytoplasm and pyknotic nuclei. There was an increase of mitotic figures, compact ortho-keratosis in the stratum corneum (Plate1-D).

\section{Prophylactic Group}

The skin of mice that received retinoic acid before UVB exposure showed mild increase in epidermal thickness in comparison to their non-exposed skin. Most keratinocytes appeared normal. Occasional keratinocytic atypia and mild increase in mitotic figures in the stratum basale layer were seen. Also mild compact orthokeratosis in the stratum corneum was also seen (Plate1-E and Plate1-F).

\section{Treated Group}

The skin of mice of this group showed normal epidermal thickness similar to that their non-exposed skin. Keratinocytes and melanocytes appeared similar to those of their non-exposed skin. Stratum corneum has basket wave appearance as that of their non-exposed skin. Both the papillary and reticular dermis was similar to their nonexposed skin (Plate1-G and Plate1-H).

\section{Immuno-histochemical Results:}

Plate-2, Table -1 and Figure 1

Non-exposed Skin: (Control Group)

The normal non-exposed skin of mice showed faint reaction (yellowish brown color) in the epidermis and mild diffuse cytoplasmic activity in sebaceous glands and endothelial cells of blood vessels (Plate2-A).

The mean optical density of ICAM-1 in epidermis was 0.988 , SD was 0.071 and SEM was 0.02 .

\section{Exposed Skin: \\ Radiated Group}

Expression of ICAM-1 showed marked diffuse cytoplasmic activity in the epidermis, sebaceous glands and blood endothelial cells (Plate 2-B).

The mean optical density of ICAM-1 in epidermis was 1.112 , SD was 0.086 and SEM was 0.025 .

The statistical analysis showed highly significant increase in the mean optical density of ICAM-1 expression in the 
epidermis in comparison to that of their non exposed area $(\mathrm{p}<0.001)$.

\section{Prophylactic Group}

Expression of ICAM-1 showed mild diffuse cytoplasmic activity in the epidermis, sebaceous glands and blood endothelial cells (Plate 2-C).

The mean optical density of ICAM-1 in epidermis was 1.116, SD was 0.095 and SEM was 0.027 .

The statistical analysis showed mild significant increase in the mean optical density of ICAM-1 expression in the epidermis in comparison to that of their non exposed area $(\mathrm{p}<0.05)$.

\section{Treated Group}

Expression of ICAM-1 was similar to that of non-exposed skin (Plate 2-D).

The mean optical density of ICAM-1 in epidermis was 1.026 , SD was 0.047 and SEM was 0.014 .

The statistical analysis showed nonsignificant increase in the mean optical density of ICAM-1 expression in the epidermis in comparison to that of their non exposed area $(\mathrm{p}>0.05)$.

Table -1 Effect of exposure to ultraviolet-B rays on the ICAM-1 expression in skin of mice Before and after topical Retinoic acid

\begin{tabular}{|c|c|c|c|c|c|}
\hline & Non-E & Radiated & Prophylactic & Treated & \\
\hline Mean & 0.988 & 1.112 & 1.116 & 1.026 & \\
\hline SD & 0.071 & 0.086 & 0.095 & 0.047 & \\
\hline SEM & 0.02 & 0.025 & 0.027 & 0.014 & \\
\hline \multirow[t]{2}{*}{ t-Test } & & $\begin{array}{l}\text { Non-Exposed } \\
\text { Radiated }\end{array}$ & $\begin{array}{l}\text { vs Non-Exposed } \\
\text { Prophyl. }\end{array}$ & $\begin{array}{l}\text { vs } \begin{array}{l}\text { Non-Exposed } \\
\text { Treated }\end{array} \\
\end{array}$ & vs \\
\hline & & 0.000908 & 0.00116 & 0.14 & \\
\hline $\mathrm{p}$-value & & $\mathrm{p}<0.001$ & $p<0.005$ & $p>0.05$ & \\
\hline Significance & & Increase & Increase & Non-significan & \\
\hline
\end{tabular}

N.B. 1-Number of readings was (240 readings per group).

2- $\mathrm{SD}=$ Standard deviation $\mathrm{SEM}=$ Standard error of mean $\quad \mathrm{t}$-Test= Student's T test p-value $=$ Probability

3- O.D.=Optical Density 4- $\quad \mathrm{p}<0.05$ was considered as statistically significance

Figure-1 Effect of exposure to ultraviolet-B rays on the ICAM-1 expression in skin of mice Before and after topical Retinoic acid

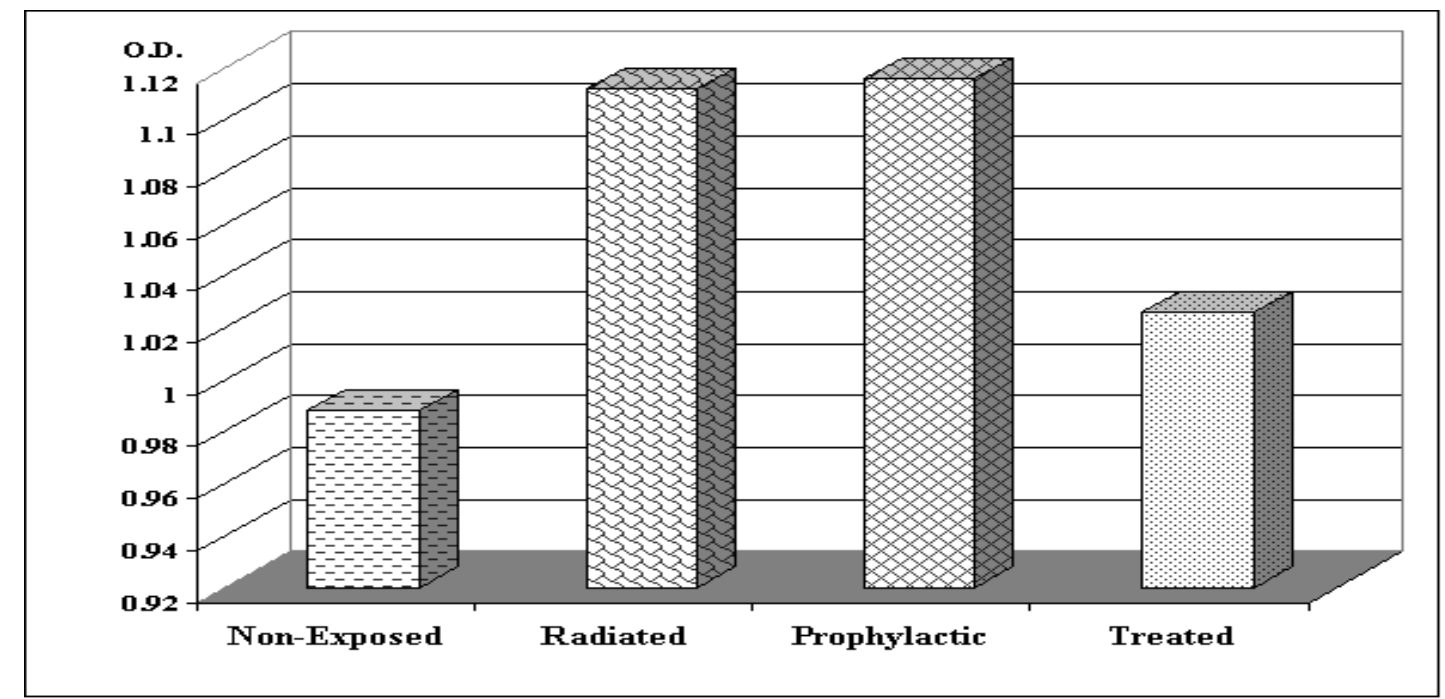


Plate - 1

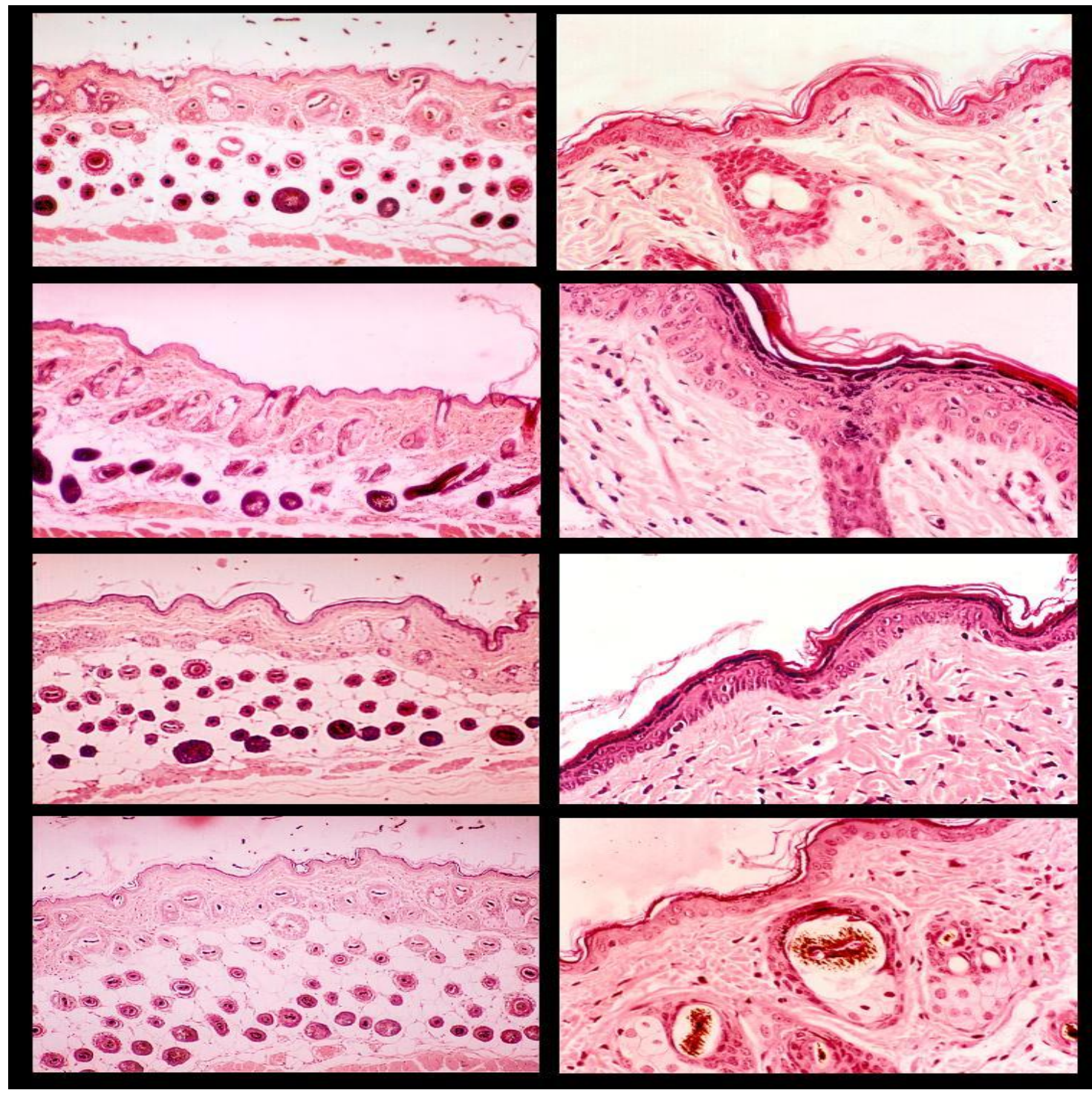

1-A A computerized photomicrograph of longitudinal section in the non-exposed skin of mice (Control group), showing the normal healthy epidermis, dermis and hypodermis. (Hx and E. stain, X100)

1-B A computerized photomicrograph of longitudinal section in the non-exposed skin of mice, showing very thin epidermis, and the underlying dermal collagenous fibers; fine in the dermal papillae and dense irregular in reticular dermis. (Hx and E. stain, X400)

1-C A computerized photomicrograph of longitudinal section in the skin of mice exposed to UVB (radiated group), showing acanthosis in comparison to non-exposed skin. (Hx and E. stain, X100)

1-D A computerized photomicrograph of longitudinal section in the skin of mice exposed to UVB (radiated group), showing compact ortho-keratosis in stratum corneum, mitotic figures in epidermal cells and fragmented delicate dermal collagen bundle. (Hx. and E. stain, X400)

1-E A computerized photomicrograph of longitudinal section in the skin of mice exposed to UVB (Prophylactic group), showing mild acanthosis in comparison to non-exposed skin. (Hx and E. stain, X100)

1-F A computerized photomicrograph of longitudinal section in the skin of mice exposed to UVB (Prophylactic group), showing mild acanthosis in stratum corneum, occasional 
keratinocytic atypia and the dermis showing normal collagenous fibers organization in both papillary and reticular dermis. (Hx. and E. stain, X400)

1-G A computerized photomicrograph of longitudinal section in the skin of mice exposed to UVB (Treated group), showing normal epidermal thickness, dermis and hypodermis similar to non-exposed skin. (Hx and E. stain, X100)

1-H A computerized photomicrograph of longitudinal section in the skin of mice exposed to UVB (Treated group), showing normal epidermal thickness, dermis and hypodermis similar to non-exposed skin. (Hx and E. stain, X400)

\section{Plate - 2}
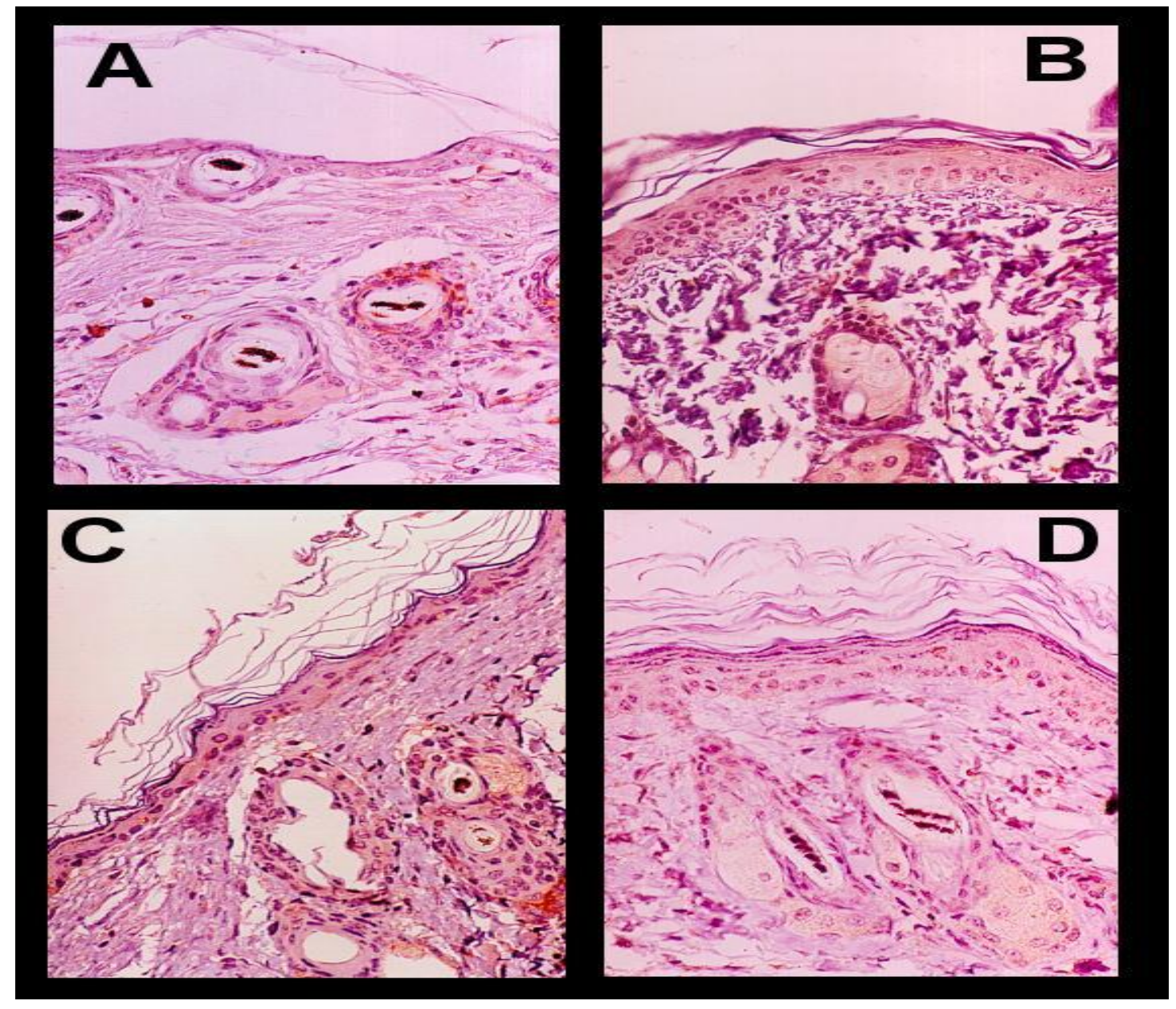

1-A A computerized photomicrograph of longitudinal section in the non-exposed skin of mice (Control group), showing faint brownish color areas of ICAM-1 reaction in the epidermis, mild diffuse cytoplasmic activity in sebaceous glands, hair follicles, and blood vessels (DAB Harris's Hematoxylin , X400)

1-B A computerized photomicrograph of longitudinal section in the skin of mice exposed to UVB (radiated group), showing marked diffuse brownish cytoplasmic activity of ICAM-1 in the epidermis, sebaceous glands (DAB Harris's Hematoxylin , X400)

1-C A computerized photomicrograph of longitudinal section in the skin of mice exposed to UVB (Prophylactic group), showing mild diffuse cytoplasmic activity of ICAM-1 in the epidermis, and sebaceous glands (DAB Harris's Hematoxylin, X400)

1-D A computerized photomicrograph of longitudinal section in the skin of mice exposed to UVB (Treated group), showing faint brownish color areas of ICAM-1 reaction in the epidermis similar to non-exposed skin (DAB Harris's Hematoxylin , X400) 


\section{Discussion}

Stratospheric ozone depletion leads to an increase of the potential harmful effects of UVR, reaching the earth, especially UVB, which are the most damaging UV wavelengths to the skin.

The use of retinoic acid to repair some of the tissue damage caused by chronic exposure of skin to UVR was reported in many studies, while its prevention role is still under investigation (Niles, 2000).

Many studies were done to find ways for preventing and treating photodamage. Recent evidence points to the importance of topical retinoids, particularly retinoic acid in repairing photodamaged skin at the clinical, structural and cellular levels (Matrisian, 1992 and Fisher et al., 1997)

In the present work, the epidermis of UVB groups showed ortho-keratosis in the stratum corneum and keratinocytic atypia, increase in mitotic figures and necrosis. While the epidermis of mice pre-treated with local retinoic acid before UVB exposure (prophylactic group) showed mild increase in its thickness with normal keratinocytes. In mice treated with local retinoic acid after UVB exposure, the skin was histologically similar to non-exposed skin.

Similar findings were observed in many previous studies on experimental animals and human (Grove et al, 1991; Yaar and Gilchrest, 1995 and Griffith, 1999).

Expression of ICAM-1 in the epidermis showed highly significant increase in optical density $(p<0.001)$, which expressed as diffuse cytoplasmic activity in the epidermis, sebaceous glands and endothelial cells of blood vessels.

Krutmann et al., (1990), demonstrated an increase in ICAM-1 expression in the epidermis after UVB exposure. In contrast, Norris et al., (1991) reported that ICAM-1 expression on keratinocytes was not increased by UVB.

The difference between the present study and that of Norris et. al. (1991) may be due to species difference as they used hairless mice. ICAM-1 is an inducible protein that appears at inflammatory conditions and mediates lymphocytesaccessory cell adhesion and may play a critical role in immune reactions (Nathens et al., 1998).

Mechanism by which UVB- induced increase in the expression of ICAM-1 in keratinocytes in present study may be attributed to capacity of UVB to enhance the release of some epidermal cytokines especially IL-10 which caused the increase in ICAM-1 expression detected in this study ( Humphries and Newham 1999).

The study concluded that retinoic acid given after UVB exposure completely reversed the morphological and ICAM-1 expression level. While, retinoic acid is given before UVB prevented some of the morphological change and not ICAM-1 expression activity.

\section{References}

1. Chaqour B., Bellon G., Seite S., Borel J. and Fourtanier A., (1997): All-transretinoic acid enhances collagen gene expression in irradiated and non-irradiated hairless mouse skin. J. Photochem. Ptobiol. 37(102): 52-59

2. Chen S., Kess I., and Tramposch K. M., (1992): Effect of All-trans-retinoic acid on UVB irradiated and non-irradiated hairless mouse skin. J. Invest. Deramatol. 98: 248254

3. Chu Hsu M., (1998): Systemic treatment of neoplastic conditions with retinoids. J. Am. Dermatol. 39: S108-113.

4. Fitzpatrick R. E., (1997): Laser resurfacing of Rhytides., Dermatologic. Clinic Vol. 15 Number 3 July: 431-446.

5. Diffey B. L., (1996): People do not apply enough sunscreen for protection. Br. Med. J. 313:342.

6. DiGiovanna J. J.,and Bethesda M., (1992): Retinoids for the future oncology. J. Am. Acad. Dermatol. 27:S34-37.

7. Fisher G. J., Datta S. C., Varani J., and Voorhess J. J., (1997): Pathophysiology of premature skin aging induced by ultraviolet light. New Engl. J. Med. 337: 1419-1428.

8. Gearing A. and Newman W., (1994): Circulating adhesion molecules in disease. Immunol. Today. 14:505-512. 
9. Griffith C. E., (1999): Drug treatment of photoaged skin. Drugs aging. Apr. 14.3: 289-301.

10. Grove G. L., Grove M. J., and Leyden J. J., (1991): Skin replica analysis of photodamaged skin after therapy with tretinoin emollient cream. J. Am. Acad. Dermatol. 25: 231-237.

11. Humphries M. J. and Newham P., (1999): The structure of cell adhesion molecules. Cell. 69:11-25.

12. Kaminar M. S., (1995): Photodamage magnitude of the problem from photodamage. (ed) Blackwell Science. Cambridge. 1: 1-11

13. Krutmann J., Kock A. and Mollar A.,(1990): Tumor necrosis factor beta and ultraviolet radiation are potent regulators of human keratinocytes ICAM-1 expression. J. Invest. Dermatol. 95: 127139.

14. Leyden J. , (2001): What is photoaged skin? European Journal of Dermatology. Vol. 11, Issue 2, March- April 2001: 165171.

15. Lobb R. R, (1992): Integrinimmunoglobulin super-family interaction in endothelial- leucocytes adhesion. Adhesion: Its role in inflammatory Diseases. J. Invest. Dermatol. 45 : 871877.

16. Lonati A., Mommaas M. A., and Mascolini G., (1996): Keratinocytes resident in normal human skin constitutively express at low levels, the intercellular adhesion molecule-1. In situ immuno-electron-microscopy study. Br. J. Dermatol. 135: 32-35.

17. Matrisian L. M., (1992): The matrixdegrading metalloproteinases. Bioassays. 14: 455-463.

18. Nathens A. B.; Bitar R. and Watson R. W., (1998): Thiol-mediated regulation of ICAM-1 in endotoxin-induced acute lung injury. J. Immunol. 160: 2959-2969.

19. Niles R. M., (2000): Recent advances in the use of vitamin A (Retiniods) in the prevention and traement of cancer. Nutrition 16(11-12): 1084-1089.

20. Norris P., Paston R. N and Thomas S., (1991): The expression of endothelial leukocyte molecule (ELAM-1), intercellular adhesion molecule (ICAM-1) and vascular adhesion molecule (VCAM1) in experimental cutaneous inflammation. Comparison sensitivity. J. Invest. Dermatol. 96: 763-770

21. Shi S. R., Key M. E. and Kalra K. L, (1991): Antigen retrieval in formaline fixed paraffin embedded tissues an enhancement method for immunohistochemical staining base on microwave oven heating of tissue sections. J. Histochem. Cytochem. 39: 741-748.

22. Taylor C. R., Stern A., and Leyden J. J., (1994): Photoaging / Photodamage and photoprotection. J. Am. Acad. Dermatol. 22: 1-15.

23. Yaar M., and Gilchrest A., (1995): biochemical and molecular changes in photoaged skin. In: Gilchrst, B. A., (ed) Photodamage. Blackwell science. Cambridge. 11: 168-184. 


\section{دراسة هيستوكيميائية مناعية علي مستوي آيكام-1 في جلا الجرذان تحت تأثير

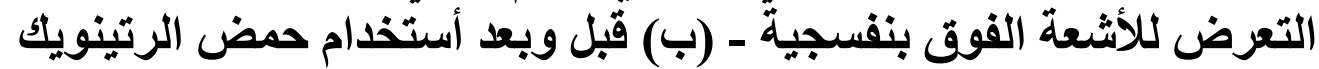
الموضعي

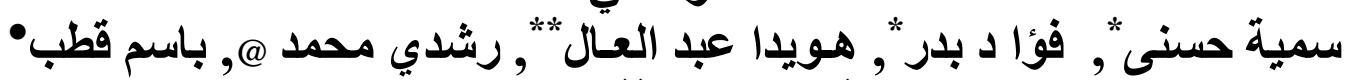

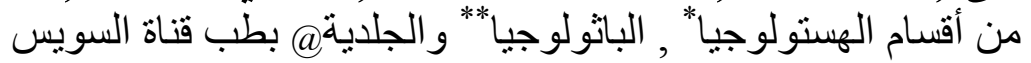

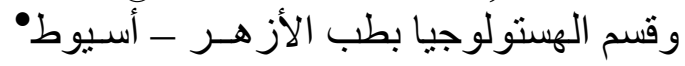

أجريت هذه الدراسة علي عدد 36 من ذكور الجرذان البالغة لدراسة تأثير التعرض للأشعة الفوق بنفسجية

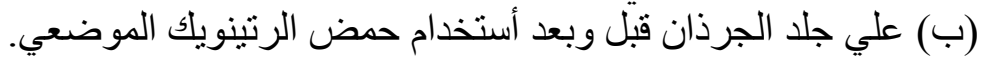

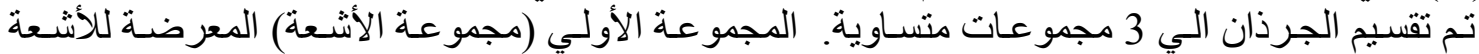

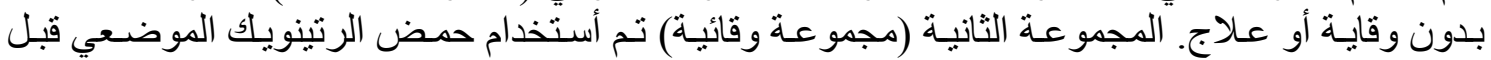

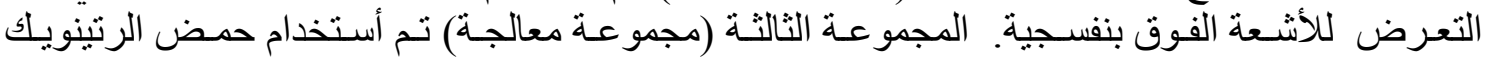

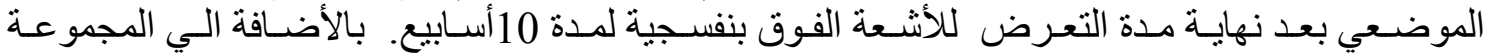

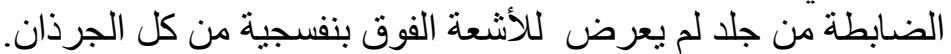

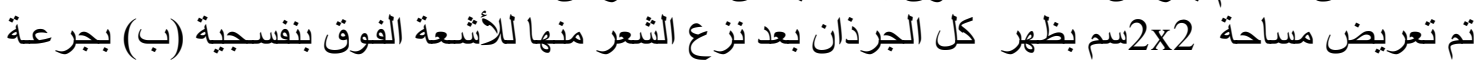

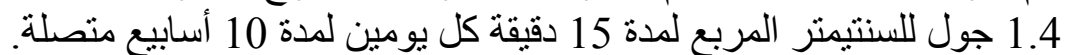

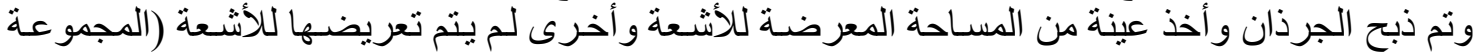

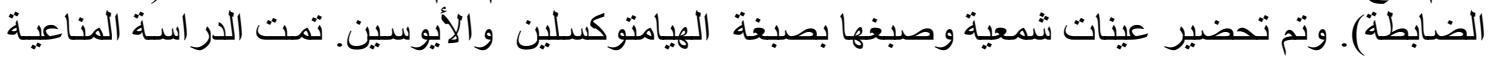

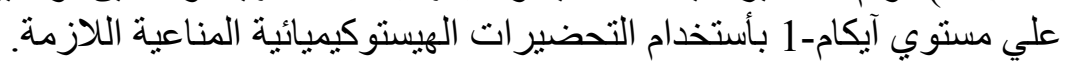
تم قياس مستوي آيكام-1 بالكثافة الضوئية بجهاز تحليل الصئية الصور بالكمبيوتر وتحليل النتائج أحصائيا.

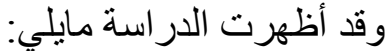
ظهور علامات أكلينيكية لأصـابة الجلد نتيجة التعرض المباثر للأثعة الفوق بنفسجية بجرذان مجموعة الأشعة.

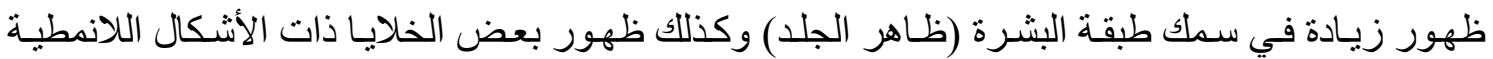

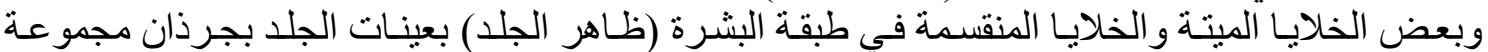
الأشعة بالمقارنة بعينات المجمو عة الضياتة الضابطة. زيادة ذات دلالة أحصائية في نسبة تركيز آيكام-1 بطبقة البطة البشرة (ظاهر الجلد) بعينات الجلد بالهجموعتين

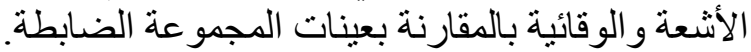

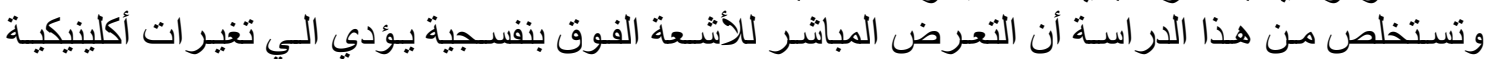

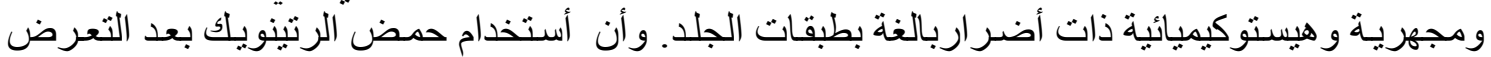

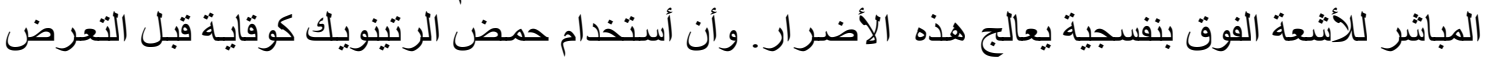

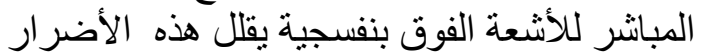
وتوصي الدراسة بعدم التعرض المباثر للأشعة الفوق بنفسجية وأستخدام حمض الرتينويك لتقليل وعلاج أضرار تعرض الجلا لأشعة الثمس. الثرس 